\title{
ОРГАНІЗАЦІЯ НАВЧАЛЬНОЇ ДІЯЛЬНОСТІ УЧНІВ ОСНОВНОЇ ШКОЛИ ІЗ ВИКОРИСТАННЯМ ПРОЕКТНИХ ТЕХНОЛОГІЙ У ПРОЦЕСІ НАВЧАННЯ ПРИРОДНИЧИХ ПРЕДМЕТІВ ЯК УМОВА ЗДОРОВ'ЯЗБЕРЕЖУВАЛЬНИХ ТЕХНОЛОГІЙ
}

Дишлева І. М. Організація навчальної діяльності учнів основної школи із використанням проектних технологій у процесі навчання природничих предметів як умова здоров'язбережувальних технологій.

У статті окреслено напрями організації навчальної діяльності учнів основної школи із використанням проектних технологій у процесі навчання природничих предметів як умова здоров'язбережувальних технологій. Висвітлено структурні особливості моделювання проектів у процесі навчання природничих предметів. Обгрунтовано сутнісні характеристики здоров'язбережувальних технологій, застосовуваних у процесі навчання природничих предметів учнів основної школи.

Ключові слова: учні основної школи, дидактичні умови, здоров'язбережувальні технології, проектні технології.

Дышлева И Н. Организация учебной деятельности учащихся основной школы с использованием проектных технологий в процессе изучения естественных предметов как условие здоровьесберегающих технологий.

В статье очерчены направления организации учебной деятельности учеников основной школы с использованием проектных технологий в процессе обучения природоведческих предметов как условие здоровьесберегающих технологий. Осветлены структурные особенности моделирования проектов в процессе обучения природоведческих предметов. Обоснованы сущностные характеристики здоровьесберегающих технологий, которые используются в процессе обучения природоведческих предметов учеников основной школы.

Ключевые слова: ученики основной школы, дидактические условия, здоровьесберегающие технологии, проектные технологии.

Dyshleva I. H Organization of student learning using primary school of design technology in education as a condition of items natural history of health technologies.

The article outlines the directions of the organization of training activities with primary school pupils using design technology in the learning process of natural history subjects as a condition of health-technology. Lightened structural features of modeling projects in the learning process of natural history subjects. Justified by the intrinsic characteristics of health promoting technologies that are used in the learning process of natural history objects primary school pupils.

Key words: primary school pupils, teaching conditions, health-saving technology, design technology.

Організація навчальної діяльності учнів основної школи із використанням проектних технологій у процесі навчання природничих предметів як умова здоров'язбережувальних технологій передбачає розроблення дидактичних умов ефективної їх реалізації.

Ефективність упровадження здоров'язбережувальних технологій забезпечується активним використанням проектів у процесі навчання природничих предметів. Проективні технології становлять своєрідну модель управління процесом професійного становлення майбутніх соціальних педагогів. Слушною $є$ думка щодо аналізованого аспекту організації навчальної діяльності учнів основної школи І. Зимньої про те, що проективність освіти спрямована на формування проектної культури тих, хто навчається. Проектна культура $\epsilon$ корелятивною загальною формою реалізації мистецтва планування, прогнозування, творення, виконання та оформлення, і покликана об'єднати два до цього часу не поєднані напрями: гуманітарнохудожній та науково-технічний. Не викликає заперечень, що «проектність - освітня тенденція майбутнього» [2, с. 59]. 
Аналіз сутності та можливостей проектного методу дозволяє стверджувати, що обсяг використання проектної технології у процесі організації навчальної діяльності учнів основної школи може бути значно ширшим, ніж у традиційно усталеній шкільній практиці. Звернення загальноосвітньої педагогічної освіти до технології навчального проектування дозволяє нам припустити, що під час навчального проектування можуть створюватися умови, які сприятимуть реалізації здоров'язбережувальних технологій.

У зв'язку $з$ тим, що в педагогічній науці проектна діяльність як дидактична умова здоров'язбережувальних технологій не вивчалася, обгрунтування ії̈ використання у практиці навчання природничих предметів учнів основної школи відсутне, тому виникла необхідність дослідження окресленої проблеми.

У контексті розвитку нових освітніх технологій навчальні проекти посідають особливе місце як засіб максимального наближення особистості до реального життя та залучення ііі до розв'язання конкретних завдань у просторі міжособистісного та ділового спілкування й співпраці $[3 ; 6]$. Якщо раніше освіта розглядалась як сукупність знань, то нині вона трактується як засіб для інтеграції особистості в навколишній світ, що вимагає вміння спілкуватися і співпрацювати.

В основу методу проектів покладено розвиток пізнавальних, творчих навичок, уміння самостійно конструювати свої знання й орієнтуватись в інформаційному просторі, розвиток критичного мислення. На нашу думку, окрім цього, метод проектів дозволяє навчити учнів працювати в команді, в групі, підпорядковувати власні інтереси інтересам команди, якщо вони спрямовані на успіх проекту. Робота над індивідуальним завданням у межах групової роботи над проектом стимулює учня до пошуку нестандартних шляхів розв'язання поставленої задачі, спонукаючи його до самоосвіти, оскільки від його особистого внеску до загального проекту залежить успіх всієї команди і ставлення членів команди до учня.

Проект - це сукупність певних дій, документів, попередніх текстів, задум для створення реального об'єкта, предмета, створення різного роду теоретичного продукту. Сутність методу проектів полягає у стимулюванні інтересу учнів основної школи до визначеної проблеми, оволодінні необхідними знаннями й навичками для іiї розв'язання, організації проектної діяльності, практичному застосуванні отриманих результатів.

Метод проектів грунтується на ідеї, що відображає сутність поняття «проект», його прагматичну спрямованість на результат, отриманий під час розв'язання практично чи теоретично значущої проблеми. Головним $є$ той факт, що результат спільної діяльності можна побачити, осмислити й застосувати в реальній практичній діяльності. Щоб домогтися такого результату, треба привчати учнів основної школи самостійно мислити, знаходити й застосовувати необхідні аргументи задля доведення істинності судження, слушності думки тощо, формулювати й розв'язувати проблеми, використовуючи для цього знання 3 різних галузей, прогнозувати результати і можливі наслідки різних варіантів розв'язання проблеми, встановлювати причинно-наслідкові зв'язки.

Успіх застосування методу проектів залежить від того, наскільки учні захочуть самостійно чи спільними зусиллями вирішувати проблему, застосовувати необхідні знання, одержати реальний і відчутний результат. Актуальність використання методу проектів зумовлена такими причинами: необхідністю не стільки передавати учням певну суму знань, скільки навчити їх здобувати ці знання самостійно й використовувати для розв'язання нових пізнавальних i практичних задач; актуальністю розвитку в учнів основної школи комунікативних навичок, умінь працювати в різних групах, виконувати різні соціальні ролі (лідера, виконавця, посередника тощо), долати конфліктні ситуації; необхідністю широких людських контактів, ознайомлення з різними культурами, поглядами на одну проблему; значущістю для діяльності людини вмінь користуватися дослідницькими методами: збирати необхідну інформацію, аналізувати іiі, висувати гіпотези, робити висновки.

Метод проектів надає кожному учневі змогу розвивати власні пізнавальні інтереси, вміння самостійно конструювати свої знання, орієнтуватися в інформаційному просторі. Цей метод завжди орієнтований на самостійну діяльність учнів основної школи - індивідуальну, парну, групову, яку вони виконують упродовж визначеного відрізка часу. Метод проектів забезпечує успішне розв'язання проблеми, що передбачає, з одного боку, використання сукупності різноманітних методів і засобів навчання, а з іншого - необхідність інтегрування знань та умінь iз різних галузей науки, техніки, культури, повсякденного життя тощо. Результати виконання 
проекту мають теоретичну, практичну й акмеологічну значущість для виконавців: якщо розв'язується теоретична проблема, то конкретним $є$ іï розв'язання; якщо практична конкретний результат, готовий до впровадження. Тому метод проектів сприяє створенню соціально значущих ситуацій, а згідно 3 концепцією Л. Виготського [1], психічний розвиток людини визначається соціальною ситуацією, тобто ії̈ статусом у суспільстві, системою стосунків із дорослими і ровесниками. При цьому соціальна ситуація розвитку не створюється ззовні: вона створюється в процесі живого спілкування між людиною і середовищем, яке ії оточує. Метод проектів містить у собі сукупність дослідницьких, пошукових, проблемних методів, творчих за своєю сутністю, тому цей метод можна розглядати як такий, що сприяє творчому розвитку учня, використанню ним певних навчально-пізнавальних прийомів, які в результаті самостійних дій учнів основної школи надають змогу розв'язати ту чи іншу проблему. Крім того, метод проектів передбачає обов'язкову презентацію результатів.

Особливого значення при цьому набуває вміння вчителя-предметника організувати спільну діяльність учнів основної школи у групі. Аналізуючи структуру спільної діяльності [7; 8], можна виокремити такі іiї основні компоненти: предмет, зміст спільної діяльності, функції учасників спільної діяльності, функціонування (індивідуальний внесок кожного учасника в спільну діяльність).

Виокремимо основні вимоги до використання методу проектів: формулювання значущої в дослідницькому i творчому аспекті проблеми (задачі), яка вимагає для розв'язання інтегрованого знання, дослідницького пошуку; практична, теоретична, пізнавальна значущість передбачуваних результатів; самостійна (індивідуальна, парна, групова) діяльність учнів основної школи; структурування змістовної частини проекту з визначеними результатами окремих етапів; використання дослідницьких методів, що передбачає певну послідовність дій: обговорення методів дослідження, обговорення способів оформлення кінцевих результатів, збір, систематизація й аналіз отриманих даних, підведення підсумків, оформлення результатів, їх презентація, висновки, висування нових проблем дослідження [4].

Вибір тематики проектів у різних ситуаціях може бути різним залежно від видів проектів, що класифікуються за характером домінуючої діяльності [4]: 1) пошуковий, дослідницький, інформаційний, творчий, ігровий, конструкційний, практико-орієнтований; 2) за мірою реалізації міжпредметних зв'язків: монопредметний проект, у рамках однієї галузі знань; міжпредметний проект, на межі різних галузей знань; позапредметний проект; 3) за характером координації проекту: безпосередній - суворої й довільної регламентації; 4) опосередкований, прихований - прихований, неявний; 5) за характером контактів: серед учнів основної школи однієї групи (півгрупи), потоку, факультету, всього навчального закладу; 6) за складом учасників проекту: індивідуальний, колективний, парний, груповий, масовий; 7) за характером партнерських взаємин між учасниками проектної діяльності: кооперативні, змагальні, конкурсні; 8) за тривалістю виконання проекту: довготривалий, середньої тривалості - від тижня до місяця, короткостроковий.

Доведено ефективність упровадження проектів, спрямованих на реалізацію здоров'язбережувальних технологій у процесі навчання природничих предметів учнів основної школи.

Один і той самий проект може бути класифікований за кількома параметрами одночасно. Дослідницькі проекти виконуються за логікою наукового дослідження і мають структуру, наближену до справжнього наукового дослідження. Творчі проекти відрізняються відповідним оформленням результатів. Такі проекти не мають детальної структури спільної діяльності учасників, оскільки вона тільки планується, а далі розвивається відповідного до вимог щодо кінцевого результату, логіці спільної діяльності та інтересам учасників проекту.

У рольових, ігрових проектах структура також накреслюється і залишається відкритою до завершення роботи. Учасники виконують певні ролі, зумовлені характером і змістом проекту.

Інформаційні проекти спрямовані на збір інформації про визначений об'єкт чи явище і передбачають ознайомлення учасників проекту з цією інформацією, іiї аналіз і узагальнення фактів, призначених для широкої аудиторії. Такі проекти часто інтегруються в дослідницькі проекти і стають їх органічною частиною.

Прикладні (практико-орієнтовані) проекти відрізняє чітко виражений із самого початку результат діяльності його учасників: він обов'язкого орієтований на соціальні інтереси самих учасників. Такі проекти вимагають ретельно продуманої структури, сценарію діяльності його 
учасників 3 визначенням функцій кожного 3 них, чітких висновків, тобто оформлення результатів проектної діяльності й участі кожного в оформленні кінцевого продукту.

Н. Матяш виокремлює такі стадії виконання проекту: обгрунтування, усвідомлення та прийняття ідеї, технологічна розробка ідеї, практична робота над нею, апробація об'єкта в роботі, доопрацювання й самооцінка творчого рішення ідеї, що становлять послідовні розгорнуті етапи саморегуляції діяльності в цілому, а не тільки проектної діяльності [5, с. 149150]. Кожен етап повторюється в процесі виконання різних проектів багаторазово, стає предметом спеціальної рефлексії, реалізується щоразу на новому матеріалі та у нових конкретних умовах i, внаслідок цього, засвоюється як загальний алгоритм діяльності, загальний засіб іiї існування. Унаслідок цього учні мають змогу засвоєння загального засобу саморегуляції діяльності. Така система саморегуляції діяльності може бути перенесеною як на матеріал інших навчальних предметів, так і за межі навчальної діяльності. Тому проектна діяльність $є$ одним 3 потужних факторів формування особистості, оскільки система саморегуляції входить до складу компонентів ії̈ структури.

Під час роботи над проектом учитель-предметник допомагає учням у пошуку джерел, які будуть корисними їм у роботі над проектом; сам $\epsilon$ джерелом інформації; координує весь процес; підтримує й заохочує учнів основної школи; підтримує безперервний зворотній зв'язок, для того щоб допомагати просуванню учнів основної школи у роботі над проектом.

Аналіз літературних джерел свідчить про наявність певних обмежень у використанні проектної діяльності, а саме: низька мотивація учителів-предметників до використання цієї технології; низька мотивація тих, хто навчається, до участі у проекті; недостатній рівень сформованості у них вмінь проектної діяльності; нечіткість визначення критеріїв оцінки відслідковування результатів роботи над проектом.

У зв'язку з другим обмеженням наведемо кілька прийомів, які забезпечують виявлення зацікавленості учнів основної школи у проектуванні:

1. Пояснення сутності проектної технології - висвітлення значущості проектної роботи, детальна характеристика послідовності дій автора проекту.

2. Анотування переліку можливих тем проектів (не менш 10-15 тем). Важливо прокоментувати можливі результати, очікувані проектні рішення, здійснити уявне моделювання.

3. Презентація варіантів виконаних проектів. У процесі представлення варіантів різних проектів необхідно ознайомити учнів зі змістом та обсягом проекту, вимогами до його оформлення; акцентувати увагу на елементах творчості; уявити сильні та слабкі сторони проектів; повідомити критерії оцінювання тощо [4, с. 9-10; 8, с. 276-277].

Вище зазначене дозволяє виокремити й охарактеризувати такі головні етапи проектної діяльності учнів основної школи (розроблення соціокультурного/предметного проекту): пошуково-дослідницький, технологічний, оформлення результатів, презентація (захист проекту), рефлексія.

Конкретизація сутності й можливості проектної діяльності в забезпеченні дидактичних умов здоров'язбережувальних технологій шляхом залучення учнів основної школи до проектної діяльності дозволяє перейти до розв'язання проблеми соціокультурної адаптації особистості в контексті її становлення.

\section{Література}

1. Выготский Л. С. Педагогическая психология / Л. С. Выготский. - М. : Педагогика-Пресс,1996. 536 с. 2. Зимняя И. Педагогическая психология : [учебник для вузов] / И. Зимняя. - М. : Логос, 2001. 384 с. 3. Інформаційний збірник Міністерства освіти України. - К. : Освіта, 1994. - № 5-6. 4. Коберник О. М. Проектування навчально-виховного процесу: управлінський аспект / О. М. Коберник // Освіта і управління : науково-практичний журнал. - 1997. - Т. 1. - № 4. - С. 43-50. 5. Матяш Н. В. Генезис и сущность понятия «Проектная деятельность школьников») / Н. В. Матяш // Совершенствование технологического образования учащейся молодёжи : сб. материалов международной научнопрактической конференции «Технологическое образование сельских школьников в современных условиях» (19-21 сентября 2000 г.) / под ред. Р. А. Галустова. - Армавир, АГПИ, 2000. - С. 146-154. 6. Павленко Ю. В. Історія світової цивілізації : Соціокультурний розвиток людства / Ю. В. Павленко. К. : Либідь, 1999. - 380 с. 7. Підласий І. П. Діагностика та експертиза педагогічних проектів: [навч. посіб.] / І. П. Підласий. - К. : Україна, 1998. - 343 с. 8. Шамова Т. И. Технология проектного обучения / Т. И. Шамова // Реализация новых управленческих и педагогических технологий как средство развития учреждений образования. - М. : МГПУ, 1998. - С. 50-53. 